\title{
Death Cart (La Muerte en su Carreta)
}

\section{Miguel de Baca}

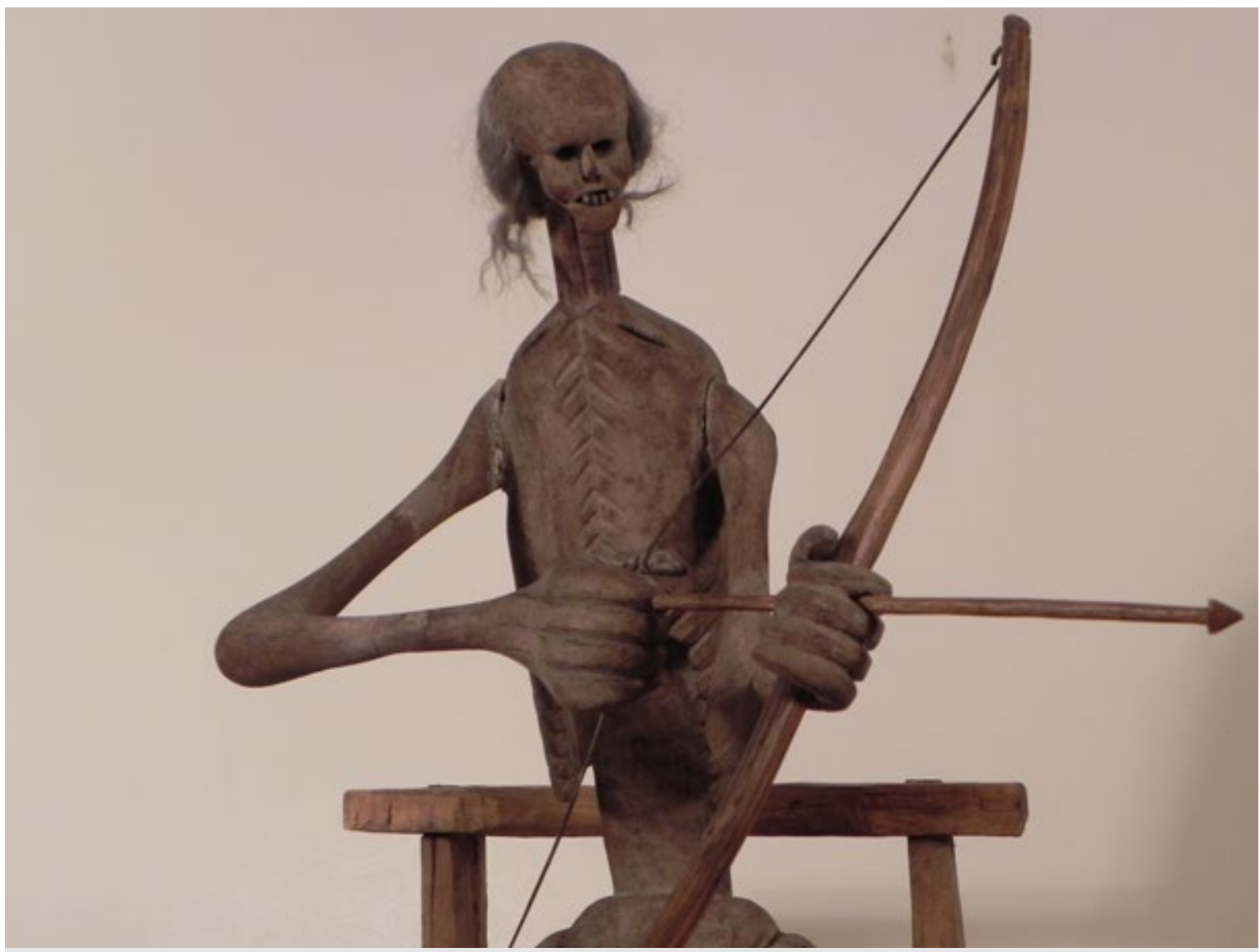

Nasario López, Death Cart (La Muerte en su Carreta), ca. 1860

This dramatic death cart is an object that was used in acts of corporal penance performed by the Hermanos de la Fraternidad Piadosa de Nuestro Padre Jesús Nazareno (Brothers of the Pious Fraternity of Our Father Jesus of Nazareth). The "Penitente Brotherhoods," as they are also known, were secretive, lay-religious fraternal organizations that served the spiritual needs of Hispanic Roman Catholics in the remotest stretches of northern New Mexico and southern Colorado in the nineteenth and early twentieth centuries. The death cart was a central prop in the brothers' Good Friday re-enactment of the Passion of Christ, which became increasingly recognized by outsiders for its violence, flagellations, and culmination in a pseudo-crucifixion. Although the use of portable objects in religious plays has its roots in medieval Spain, the death cart is unique to this region and has a ritual, rather than a didactic, function. During the performance, an elected brother attached the heavy chassis to his torso with a horsehair rope and dragged it from the morada (meetinghouse) along the path to the calvario (Calvary site), inflicting abrasions upon his body, as a demonstration of his faith and desire for closer union with God.

Although the look of the death cart varied from one artisanal studio to another, the 
typical example, as shown here, was comprised of two elements: the cart and, inside it, the statue of La Muerte, a commanding reminder of death's ever-presence. The cart was assembled of thin wooden splints that shape the four sides. These were joined together with rawhide and traditional mortise and tenon joints (where a peg or tenon carved on one piece was glued into a hole or mortise on the other). The artisan then made, out of a bulkier wood, the floor, the main frame of the chassis, the two rough-hewn wheels with wooden hubs, and the axle running between them. Wooden roller bearings slipped through the axle on each end braced the cart, chassis, and wheels. A shallow chair occupied the cart's interior. Crafted of carved wood, the chair was also held together by mortise and tenon joints. The sculpture of La Muerte seated on this chair asserted a powerful visual presence. The statue itself was a carved wooden skeleton that might be either unclothed or wrapped in a black woolen or silk mantilla (a veil or shawl, generally of lace, worn over the head and shoulders). The figure, furthermore, was striated on the torso and legs to indicate sections of bone. It was also painted with a light gesso. The figure's skull featured narrowly set eyes, sometimes inlaid with obsidian or some other black stone, and the wide forehead and pinched features lent an overall impression of desiccation.

The allegorical significance of La Muerte is semantically obscure. In Penitente communities, she was sometimes referred to as Nuestra comadre Sebastiana: "Our Godmother Sebastiana" or "Our good friend Sebastiana." The title comadre separated her from la madre ("the mother"), surely to distinguish her from the Holy Mother, the Virgin Mary, who avoided earthly death (according to Roman Catholic dogma, Mary's whole body and soul entered heaven in the "assumption" at the end of her life). The name "Sebastiana" is a feminine declension of the male Saint Sebastian, who is frequently depicted as martyred by arrows. By contrast, Sebastiana carries a wooden bow strung with sinew, suggesting her agency as the archer, rather than the victim.

The live body of the worshipper was the physical target of the death cart performance. The penitent faced away from the erect La Muerte, adopting a near-prone position of submission, and used rope sinews to harness the chassis to his torso. Assuming the weight of the female statue, the penitent dragged it along the path to Calvary, causing bleeding in the tissues and skin around his shoulders. Thus the death cart literally entered the penitent's body, intensifying the sense of human mortality, which La Muerte also compactly signified. Interestingly, La Muerte was the only female figure-real or allegorical-permitted in the Brotherhood's all-male ritual space. Her peculiar presence potently suggests the reversal of penetrative agency in gendered terms, and may compel us toward the further analysis of penetration as a trope of sacrifice and redemption.

The bloodiness of these originally ostensibly secret rituals reached a national reputation in the first decades of the twentieth century, attracting tourists especially from among the modernist avant-garde. Walter Ufer (1876-1936) and William Penhallow Henderson (1877-1943) were among the first East Coast painters to represent Penitente processions in their expressionistic portrayals. The renowned modern dancer Martha Graham (1894-1991) described New Mexico as possessing incomparable "ferocity"; in 1941, she choreographed El Penitente, a pastiche of the Good Friday ritual replete with 


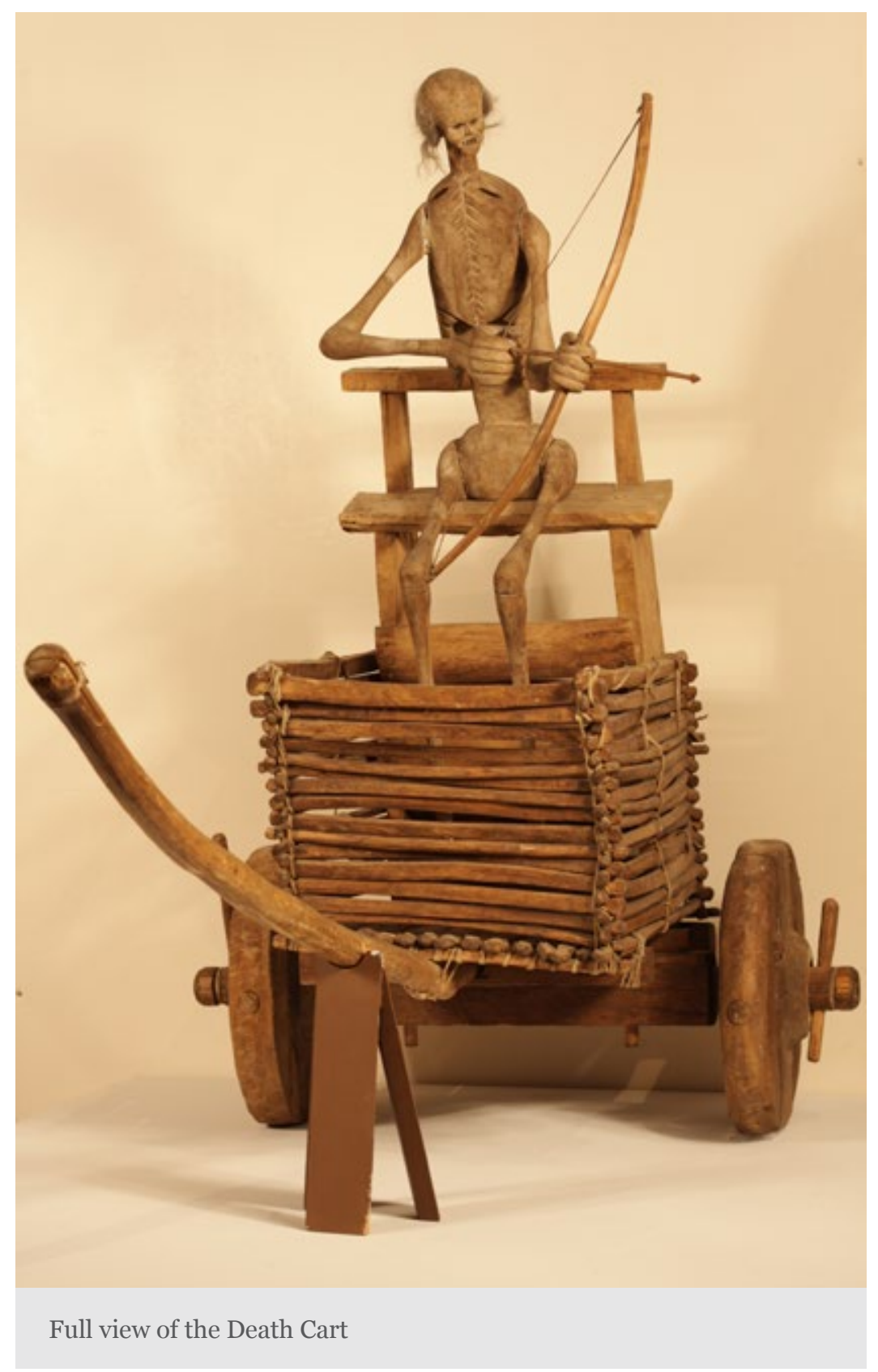

a death cart-shaped set piece in which Graham substituted her own body for La Muerte. After the Second World War, the Penitentes became much less visibly active. Still, the region's rich artisanal tradition continues to bear the imprint of the Brotherhood's distinctive material and folkloric culture.

(C) Miguel de Baca 


\section{Citation Guide}

1. Miguel de Baca, "Death Cart (La Muerte en su Carreta)," Object Narrative, in Conversations: An Online Journal of the Center for the Study of Material and Visual Cultures of Religion (2014), doi:10.22332/con.obj.2014.7

De Baca, Miguel. "Death Cart (La Muerte en su Carreta)." Object Narrative. In Conversations: An Online Journal of the Center for the Study of Material and Visual Cultures of Religion (2014). doi:10.22332/con.obj.2014.7

\section{Notes}

1. Madrina is godmother in Spanish; comadre is a term used either by parents to refer to the godmother of their child or by the godparents of the child to refer to its mother. The term can also be used to refer to an intimate female friend.

\section{Suggestions for Further Reading}

López-Pulido, Alberto. The Sacred World of the Penitentes. Washington, DC:

Smithsonian Institution Press, 2000.

Stark, Louisa R. "The Origin of the Penitente Death Cart," The Journal of American Folklore. v. 84, no. 333 (July - September 1971): 304-310.

Steele, Fr. Thomas J. (S.J.). Santos and Saints: The Religious Folk Art of Hispanic New Mexico. Santa Fe, NM: Ancient City Press, 1994.

Wroth, William. Images of Penance, Images of Mercy: Southwestern Santos in the Late Nineteenth Century. Norman, OK: Oklahoma UP for the Taylor Museum for Southwestern Studies and the Colorado Springs Fine Arts Center, 1991.

\section{Yale}

